\title{
Exploring Starch Sources for the Refreshment Process of Acetone-Butanol- Ethanol Fermentation with Clostridium Saccharoperbutylacetonicum N1-4
}

\author{
Rizki Fitria Darmayanti ${ }^{*}$, Ari Susanti ${ }^{1}$, Felix Arie Setiawan ${ }^{1,2}$, Meta Fitri Rizkiana ${ }^{1}$, Maktum \\ Muharja ${ }^{1}$, Bimo Bayu Aji ${ }^{1}$, Mizanurafi' Ghifarhadi Prasiefa ${ }^{1}$, Liony Trisinta Dewi ${ }^{1}$, Zanuba \\ Anggie Yanti ${ }^{1}$ \\ ${ }^{1}$ Department of Chemical Engineering, Faculty of Engineering, University of Jember, Jalan Kalimantan No. \\ 37, Tegal Boto, Jember 68121, Indonesia \\ ${ }^{2}$ Chemical and Biological Engineering Department, University of British Columbia, 2210 West Mall, \\ Vancouver, BC Canada V6T 1Z4, Canada
}

\begin{abstract}
Biobutanol is a renewable fuel that can be used as a gasoline substitute and a chemical feedstock. Its production using the Clostridial bacterial strain involves three steps: refreshment from a stock, a preculture for bacterial propagation, and primary fermentation for butanol production. Refreshment is an important process to activate the bacteria and multiply the stock. This process uses potato glucose media for C. saccharoperbutylacetonicum N1-4, while the use of starch from other sources has not been studied. This study aimed to understand various carbon sources' effects on this refreshment process as part of ABE (acetone-butanol-ethanol) fermentation. Starch was substituted in refreshment media with several types of potato, rice, sweet corn, and sweet potato at $15 \% \mathrm{w} / \mathrm{v}$. After 24 hours of refreshment at an ambient temperature, fermentation was run for 48 hours in TYA (tryptone-yeast-acetate) glucose media. All the starch sources could be used in the refreshment process, resulting in butanol and total solvent concentration ranging from 7.58 to $8.76 \mathrm{~g} / \mathrm{L}$ and 12.5 to $14.6 \mathrm{~g} / \mathrm{L}$, respectively. Among the samples, sweet corn provided the highest fermentation performance, with butanol of $8.76 \mathrm{~g} / \mathrm{L}$, total solvents of $14.6 \mathrm{~g} / \mathrm{L}$, average butanol productivity of $0.182 \mathrm{~g} / \mathrm{L} / \mathrm{h}$, and a butanol yield per substrate of $0.481 \mathrm{C}$-mol/C-mol. All the starchy materials used in this experiment offered potential for ABE fermentation, while sweet corn performed remarkably—-producing the highest final butanol concentration, productivity, and yield.
\end{abstract}

Keywords: Biobutanol; Potato; Rice; Refreshment; Sweet corn; Sweet potato

\section{Introduction}

The growing population's increasing energy demand has led to an urgent quest for new energy sources (Yuliansyah et al., 2019). Transportation is one of the highest energyconsuming sectors, requiring specific fuel properties (Febrianti et al., 2017). Biobutanol is among the biofuels that can be used as a substitute for gasoline in premixed combustion engines (Szulczyk, 2010). It offers better properties than ethanol vis-à-vis higher energy value, lower vapor pressure, and an octane number more similar to gasoline. No modification is needed to combust butanol in current engines, and butanol's application has improved engine performance (Merola et al., 2012; Lapuerta et al., 2017). 
Butanol has been produced using biomass feedstock by converting carbohydrates. Sugar and other carbohydrates are digestible using Clostridial species via acidogenesis and solventogenesis phases (Tashiro et al., 2013). One species can produce a large amount of butanol at an ambient temperature: Clostridium saccharoperbutylacetonicum. This strain can directly ferment various types of sugar and starch substrates, with or without hydrolysis (Zhao et al., 2018; Darmayanti et al., 2019).

Starchy vegetables have been produced at large scales to fulfill food needs (Supramono et al., 2016). Rice, potato, corn, and sweet potato are grown widely around the world in increasing quantities and qualities (Devaux et al., 2014; Jusuf and Ginting, 2014; Muthayya et al., 2014). Starchy materials derived directly from fresh vegetables provide various nutrients, especially starch, sugars, protein, and such elements as nitrogen, potassium, magnesium, sulfur, and calcium (McGill et al., 2013). Vitamins are also present in these materials, such as vitamin B in rice (Liu et al., 2019), vitamins $C$ and $E$ in corn, and vitamins $A$ and $C$ in potato and sweet potato (McGill et al., 2013). These nutrients have helped the ABE fermentation strain grow and achieve better viability (Ambarsari and Sonomoto, 2012; Mukherjee et al., 2019).

Culturing C. saccharoperbutylacetonicum from stock generally involves three main steps: refreshment of the stock with heat-shocking, a preculture to grow more cells for larger-scale fermentation, and the main fermentation in a large container for butanol production. The refreshment step has commonly used potato glucose media, which is easily made majorly from potato (15\%), glucose, ammonium sulfate, and calcium carbonate (Darmayanti et al., 2018; Hastuti et al., 2019; Zhao et al., 2019). This strain differs considerably from other Clostridial strains used as commercial media, such as reinforced clostridial media (RCM), cooked meat medium (CMM), or clostridial growth medium (CGM), which contain protein and amino acids as their main components (Li et al., 2011; Xue et al., 2012; Qureshi et al., 2014). Refreshment is a critical step to activate inactive bacteria in stock, and this step is also necessary for the stock multiplication process.

To our knowledge, the starchy materials used to refresh $C$. saccharoperbutylacetonicum have only included potatoes, especially the variety of May queen variety-large-sized potatoes that are grown mostly in Japan and Europe. Among Japan's potato varieties, only in may-queen potato media allows this strain to grow; it has been unable to grow using other varieties (Gao et al., 2016). Other starchy materials offer potential for use as the refreshment process's carbon source. While the starch content of potato, rice, corn, and sweet potato is over $30 \%$, their sugar content differs considerably, and their other components might affect cell growth and fermentation (Ambarsari and Sonomoto, 2015). ABE fermentation using different carbon sources for refreshment has not been studied. While vitamins and minerals have been reported to enhance biobutanol production (Li et al., 2014), most are present in the starch sources with various compositions; therefore, ABE fermentation using these refreshment substrates required investigation.

Accordingly, this study aimed to understand the potency and effects of various carbon sources in the refreshment process of ABE fermentation using $C$. saccharoperbutylacetonicum N1-4. The starch in refreshment media was substituted with several types of potato, rice, sweet corn, and sweet potato. We expected this substitution to widen the variety of starch sources, consequently expanding supplies for these sources. Cell growth, substrate consumption, and solvent production were studied to observe fermentation performance. These experiments revealed sweet corn as a potential starchy vegetable for biobutanol-producing refreshment media. Sweet corn was observed to result in the highest butanol concentration as a refreshment substrate. 


\section{Methods}

\subsection{Microorganisms and the Refreshment Step}

C. saccharoperbutylacetonicum N1-4 (ATCC 13564) was stored as a sand stock aseptically at an ambient temperature, and $1.5 \mathrm{~g}$ of the sand stock was inoculated in a test tube with $9 \mathrm{~mL}$ of starch glucose media, containing $150 \mathrm{~g} / \mathrm{L}$ of grated fresh granola potato, Tess potato, small potato, rice, sweet corn, purple sweet potato, or Cilembu sweet potato, $10 \mathrm{~g} / \mathrm{L}$ of glucose, $0.5 \mathrm{~g} / \mathrm{L}$ of $\left(\mathrm{NH}_{4}\right)_{2} \mathrm{SO}_{4}$, and $3 \mathrm{~g} / \mathrm{L}$ of $\mathrm{CaCO}_{3}$. C. saccharoperbutylacetonicum N1-4 (ATCC 13564) was then heated in boiling water at a temperature of $100^{\circ} \mathrm{C}$ for one minute. The suspensions were incubated at an ambient temperature for 24 hours in an anaerobic condition using an oxygen adsorber. The suspensions were then stored at $4^{\circ} \mathrm{C}$ as working stocks.

Next, $1 \mathrm{~mL}$ of the spore suspension from the working stock was refreshed by adding 9 $\mathrm{mL}$ of starch glucose media (10\% inoculation) containing $150 \mathrm{~g} / \mathrm{L}$ of grated fresh granola potato, Tess potato, small potato, rice, sweet corn, purple sweet potato, or Cilembu sweet potato, $10 \mathrm{~g} / \mathrm{L}$ of glucose, $0.5 \mathrm{~g} / \mathrm{L}$ of $\left(\mathrm{NH}_{4}\right)_{2} \mathrm{SO}_{4}$, and $3 \mathrm{~g} / \mathrm{L}$ of $\mathrm{CaCO}_{3} . C$. saccharoperbutylacetonicum N1-4 (ATCC 13564) was then heated in boiling water at a temperature of $100^{\circ} \mathrm{C}$ for one minute. These solutions were incubated at an ambient temperature for 24 hours anaerobically, using an oxygen adsorber.

\subsection{Preculture}

We cultured $10 \mathrm{~mL}$ of the inoculated strain in $90 \mathrm{~mL}$ of TYA media containing $3 \mathrm{~g} / \mathrm{L}$ of $\mathrm{CH}_{3} \mathrm{COONH}_{4}, 0.3 \mathrm{~g} / \mathrm{L}$ of $\mathrm{MgSO}_{4} .7 \mathrm{H}_{2} \mathrm{O}, 2 \mathrm{~g} / \mathrm{L}$ of yeast extract (Himedia, Mumbai, India), $6 \mathrm{~g} / \mathrm{L}$

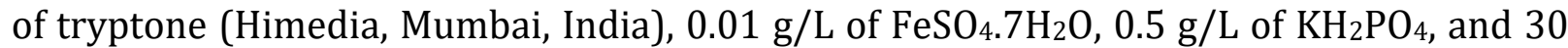
$\mathrm{g} / \mathrm{L}$ of glucose at a $10 \%(\mathrm{v} / \mathrm{v})$ inoculum. The media's $\mathrm{pH}$ was set to $6.50 \mathrm{using} \mathrm{HCl} 0.1 \mathrm{M}$. After inoculation, the culture broth was incubated at an ambient temperature for 48 hours anaerobically, using an oxygen adsorber.

\subsection{Analysis}

Cell density was measured using the broth's optical density at $562 \mathrm{~nm}$ with a UV visible spectrophotometer (GoDirect, SpectroVis Plus Spectrophotometer, Vernier, USA). One unit of optical density was equal to $0.246 \mathrm{~g}$ in dry cell weight (Darmayanti et al., 2018).

Butanol, acetone, ethanol, acetic acid, and butyric acid were measured in the media using gas chromatography (Trace 1300, ThermoScientific, Italy) with a flame ionization detector and a TR Wax column. The column was operated at $50-190^{\circ} \mathrm{C}$. Nitrogen was used as a carrier gas.

Reduced sugar in the refreshment media and glucose in the fermentation media were analyzed using the dinitrosalicylic acid (DNS) method. The samples were diluted 10 times and mixed with a DNS reagent at a ratio of 2:3. This mixture was boiled in water at a temperature of $100^{\circ} \mathrm{C}$ for 10 minutes and then cooled in iced water for 10 minutes. Once it was returned to an ambient temperature, its absorbance at $540 \mathrm{~nm}$ was measured using a UV-vis spectrophotometer.

\subsection{Parameter Determination}

Fermentation parameters were calculated using the following equations. Solvent productivity was calculated using Equation 1:

$$
P_{S}=\frac{[S]}{t}
$$

where $P_{S}$ is the solvent productivity $(\mathrm{g} / \mathrm{L} / \mathrm{h}),[S]$ is the solvent concentration $(\mathrm{g} / \mathrm{L})$, and $t$ is the time of fermentation (h).

The solvent yield, based on dry cell weight, was determined using Equation 2. 


$$
Y_{\frac{S}{D C W}}=\frac{[S]}{[D C W]_{\text {final }}}
$$

where $Y_{S} / D C W$ is the yield of the produced solvent, based on dry cell weight $(\mathrm{g} / \mathrm{g})$, and $[D C W]_{\text {final }}$ is the final dry cell weight $(\mathrm{g} / \mathrm{L})$.

Additionally, the solvent yield was calculated based on substrate consumption, using Equation 3. The butanol, acetone, and ethanol yield per consumed substrate was determined in carbon mole units, representing the experimental yield compared with the maximum producible butanol if all of the carbon were converted into butanol.

$$
Y_{\bar{S}}=\frac{\frac{m_{S}}{M W_{S}} \times N_{S}}{\frac{m_{G}}{M W_{G}} \times N_{G}}
$$

where $Y_{S} / G$ is the yield of the produced solvent, based on glucose consumption (C-mol/C$\mathrm{mol}$ ), and $m_{S}$ and $m_{G}$ are the mass of the solvent and the consumed glucose (g), respectively. $N_{S}$ and $N_{G}$ are the numbers of carbon atoms and glucose compounds in the solvent, respectively. $M W_{S}$ and $M W_{G}$ are the molecular weight of the solvent and glucose $(\mathrm{g} / \mathrm{mol})$, respectively.

\section{Results and Discussion}

\subsection{Media Acidity and Bacterial Growth on Batch Fermentation}

The medium we used for this study's fermentation broth was TYA with glucose as its main carbon source. This experiment was conducted to study the substrate's effect on the refreshment media in ABE fermentation. The refreshment media contained six varieties of starchy vegetables: potato (granola, Tess, and small), rice, sweet corn, and sweet potato (purple and Cilembu). Three types of potato (Tess, granola, and small) were studied since they represented high (31\%), medium (25\%), and low (15\%) starch content, respectively (Sari et al., 2013). Two types of sweet potato were selected to represent the purple and yellow (Cilembu) varieties.

The initial $\mathrm{pH}$ of all fermentation media was set at 6.50 before these media were mixed with the refreshment and preculture media. The initial $\mathrm{pH}$ values, before the main fermentation step, are shown in Table 1. They ranged between 6.60 and 6.71. After 48 hours, the fermentation broths' final $\mathrm{pH}$ values decreased slightly. The highest initial $\mathrm{pH}$, 6.71, was achieved through fermentation using sweet corn refreshment media. The lowest final $\mathrm{pH}$ value, 6.17, was achieved through the fermentation media using purple sweet potato and granola potato. Fermentation with rice refreshment media resulted in the highest $\mathrm{pH}$ value, 6.29 .

Table 1 Broth acidity and final dry cell weight of batch ABE fermentation using TYA media with $30 \mathrm{~g} / \mathrm{L}$ of glucose via C. saccharoperbutylacetonicum N1-4

\begin{tabular}{lccc}
\hline \multicolumn{1}{c}{ Starch source } & Initial $\mathrm{pH}^{\mathrm{b}}$ & Final $\mathrm{pH}^{\mathrm{c}}$ & ${\text { Final dry cell weight }(\mathrm{g} / \mathrm{L})^{\mathrm{c}}}^{\mathrm{c}}$ \\
\hline Potato (granola) & 6.66 & 6.17 & 0.7728 \\
Potato (small) & 6.68 & 6.21 & 0.6245 \\
Potato (Tess) & 6.63 & 6.19 & 0.7137 \\
Rice & 6.60 & 6.29 & 0.6153 \\
Sweet corn & 6.71 & 6.22 & 0.7570 \\
Sweet potato (Cilembu) & 6.61 & 6.23 & 0.7295 \\
Sweet potato (purple) & 6.67 & 6.17 & 0.8751 \\
\hline
\end{tabular}

a Used in refresh media $15 \% \mathrm{w} / \mathrm{v}$; ${ }^{\mathrm{b}}$ Measured at 0 hours of fermentation after 24 hours of refreshment

$c$ Measured at 48 hours of fermentation 
The fermentation broth's cell density was measured as dry cell weight. The final cell densities at 48 hours are shown in Table 1 . These values were ranged from $0.6153 \mathrm{~g} / \mathrm{L}$ to $0.8751 \mathrm{~g} / \mathrm{L}$. According to these data, a relationship between fermentation media's $\mathrm{pH}$ and dry cell weight was observed. Fermentation with a higher cell density, using purple sweet potato refreshment media, resulted in the highest final $\mathrm{pH}$ through fermentation. On the other hand, rice refreshment media demonstrated the lowest cell density and final $\mathrm{pH}$ through fermentation.

Acidity changes during ABE fermentation occurred because of the Clostridial strain's metabolic steps. Initially, acidogenesis occurred, converting sugars into organic acid and decreasing the fermentation media's pH (Li et al., 2020). This process continued with the conversion of organic acid into a solvent, which increases the media's pH (Tashiro et al., 2004). As a previous study indicated, this strain performed the highest butanol concentration at a pH close to 5.5 during fermentation (Gao et al., 2016; Oshiro et al., 2010). The higher final pH observed in the fermentation broth indicated a lower concentration of organic acid and a higher concentration of solvent. We believe cell growth affected this result. Higher cell growth leads to higher fermentation viability.

\subsection{Substrate Consumption in Batch Fermentation}

Fermentation with all substrate refreshment media effectively consumed the sugar in the broth. Table 2 shows glucose consumption during batch fermentation at 48 hours. Glucose consumption during fermentation using purple sweet potato refreshment media resulted in the highest glucose consumption, $29.55 \mathrm{~g} / \mathrm{L}$. Fermentation with rice refreshment media attained the lowest glucose consumption, $28.20 \mathrm{~g} / \mathrm{L}$.

Table 2 Substrate consumption of batch ABE fermentation using TYA media with $30 \mathrm{~g} / \mathrm{L}$ of glucose via C. saccharoperbutylacetonicum N1-4

\begin{tabular}{lcccc}
\hline \multicolumn{1}{c}{ Starch source } & $\begin{array}{c}\text { Final glucose } \\
\text { concentration } \\
(\mathrm{g} / \mathrm{L})^{\mathrm{b}}\end{array}$ & $\begin{array}{c}\text { Glucose } \\
\text { consumption } \\
(\mathrm{g} / \mathrm{L})\end{array}$ & $\begin{array}{c}\text { Glucose } \\
\text { consumption } \\
\text { rate }(\mathrm{g} / \mathrm{L} / \mathrm{h})^{\mathrm{c}}\end{array}$ & $\begin{array}{c}\text { Reducing sugar } \\
\text { in refresh }(\mathrm{g} / \mathrm{L})^{\mathrm{d}}\end{array}$ \\
\hline Potato (granola) & 0.467 & 29.53 & 0.6153 & 15.52 \\
Potato (small) & 0.509 & 29.49 & 0.6144 & 13.38 \\
Potato (Tess) & 0.474 & 29.53 & 0.6151 & 16.86 \\
Rice & 1.805 & 28.20 & 0.5874 & 16.42 \\
Sweet corn & 0.460 & 29.54 & 0.6154 & 22.56 \\
Sweet potato (Cilembu) & 0.475 & 29.52 & 0.6151 & 29.03 \\
Sweet potato (purple) & 0.452 & 29.55 & 0.6156 & 32.71 \\
\hline a Used in refresh media 15\% w/v; b Measured at 48 hours of fermentation; & \\
c Calculated as the average rate during 48 hours of fermentation; d Measured at 0 hours of refreshment
\end{tabular}

Substrates' consumption rates were calculated using averages during 48 hours of fermentation. Consequently, a relation involving glucose consumption rates was revealed: the purple sweet potato refreshment media resulted in the fastest rate, $0.6156 \mathrm{~g} / \mathrm{L} / \mathrm{h}$, while the rice refresh demonstrated the lowest glucose consumption rate, $0.5874 \mathrm{~g} / \mathrm{L} / \mathrm{h}$.

The reducing sugar in the refreshment media ranged from 13.38 to $32.71 \mathrm{~g} / \mathrm{L}$, while the glucose added to the media was only $10 \mathrm{~g} / \mathrm{L}$. These results indicated that the starchy materials contained sugar as well. Surprisingly, this finding favored the strain's growth as we had expected, with purple sweet potato refreshment media achieving the highest reducing sugar concentration at $32.71 \mathrm{~g} / \mathrm{L}$, resulting in the highest final dry cell weight (Table 1) and the fastest consumption rate.

Glucose consumption during batch fermentation using potato as a substrate in refreshment achieved a rate of $0.399 \mathrm{~g} / \mathrm{L} / \mathrm{h}$ (Ambarsari and Sonomoto, 2012). The current 
experiment's glucose consumption rate was higher than the rate found in a similar study using the same species of $C$. saccharoperbutylacetonicum N1-4 (Ambarsari and Sonomoto, 2012) and potato. Reducing sugar in the refreshment media, as well as the content of starchy materials, has been believed to affect strain growth and activity (Gao et al., 2016). Purple sweet potato provides carbon, nitrogen, and trace elements supporting cell growth. Purple sweet potato contains approximately 66\% starch, $1.5 \%$ sugar, $12 \%$ uronic acid, $6 \%$ crude protein, and $0.6 \%$ crude fat (Kim and Ryu, 1995). Moreover, amino acids-such as leucine and valine-and such trace elements as potassium, magnesium, calcium, and iron are present in purple sweet potato in remarkable amounts (Kim and Ryu, 1995; Firgianti and Sunyoto, 2018).

\subsection{Butanol Production using Various Starches in the Refreshment Step}

We conducted the main culture for ABE fermentation after 24 hours of refreshment and 15 hours of preculture. Glucose of $30 \mathrm{~g} / \mathrm{L}$ was contained in TYA media as the main substrate. The final concentrations of solvents and acids were analyzed after 48 hours. Values for butanol, acetone, ethanol, acetic acid, and butyric acid were measured directly from the fermentation broth using gas chromatography.

The final butanol concentrations resulted from our fermentations using sweet corn, at $8.76 \mathrm{~g} / \mathrm{L}$ (Figure 1), and Tess potato, at $8.17 \mathrm{~g} / \mathrm{L}$. Simultaneously, acetone was produced at about half the concentration of butanol, at $4.59 \mathrm{~g} / \mathrm{L}$ and $3.80 \mathrm{~g} / \mathrm{L}$ for sweet corn and Tess potato, respectively. Meanwhile, the highest acetone concentration was produced using purple sweet potato refreshment media. Ethanol was produced at about $1 \mathrm{~g} / \mathrm{L}$, so the total solvent concentration achieved was highest using sweet corn refreshment media, at 14.64 g/L. This concentration was higher than previous studies' corresponding concentrations using conventional batches of a single strain culture, potato (May queen), and glucose media, which achieved $12.0 \mathrm{~g} / \mathrm{L}$ in solvents (Ambarsari and Sonomoto, 2015).
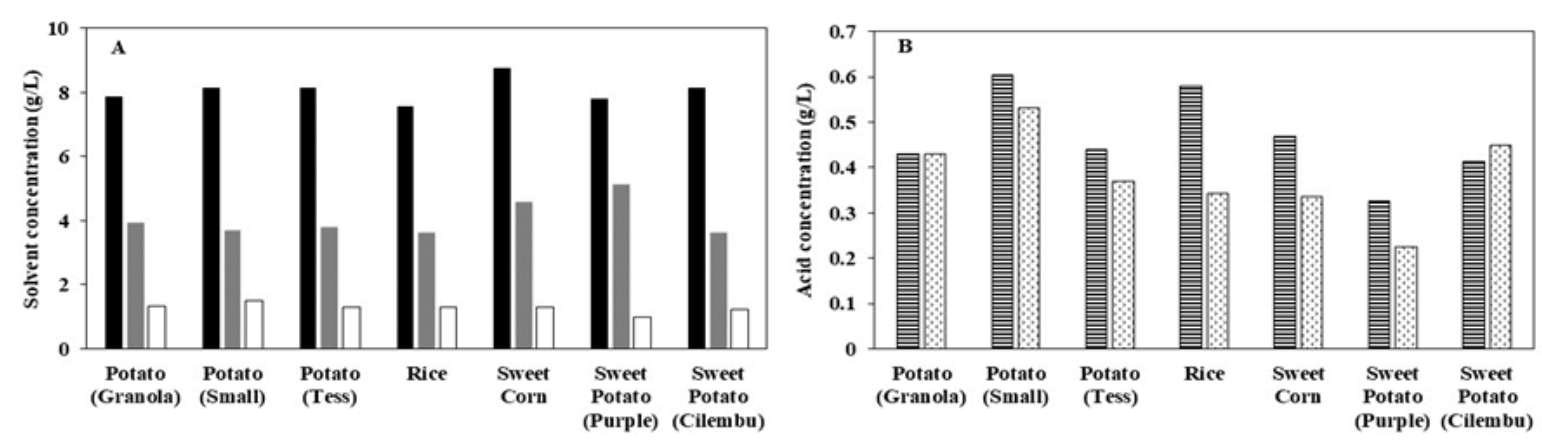

Figure 1 Solvents' (A) and acids' (B) final concentration with various starch sources in the refreshment step after 48 hours of batch ABE fermentation using TYA media with $30 \mathrm{~g} / \mathrm{L}$ of glucose via $C$. saccharoperbutylacetonicum N1-4. In A, black indicates butanol; gray indicates acetone, and white indicates ethanol. In B, stripes indicate acetic acid while dots indicate butyric acid

Figure 1 shows organic acid concentrations at 48 hours. Acetic acid concentrations ranged from 0.327 to $0.603 \mathrm{~g} / \mathrm{L}$. Meanwhile, butyric acid concentrations ranged from 0.225 to $0.531 \mathrm{~g} / \mathrm{L}$. Both of these organic acids were produced from the metabolism of sugar and then sequentially fermented into solvents. Acetic acid is the intermediate stage between acetone and ethanol production, while butyric acid is the intermediate stage in butanol production (Tashiro et al., 2013). Purple sweet potato refreshment media achieved the lowest residual unconverted acid after 48 hours of fermentation, with $0.327 \mathrm{~g} / \mathrm{L}$ and 0.225 $\mathrm{g} / \mathrm{L}$ of acetic acid and butyric acid, respectively. The strain's ability to convert organic acids was enhanced at a lower pH, near 5.5 (Tashiro et al., 2004). The purple sweet potato 
Table 3 Performance of batch ABE fermentation using TYA media with $30 \mathrm{~g} / \mathrm{L}$ of glucose via C. saccharoperbutylacetonicum N1-4

\begin{tabular}{|c|c|c|c|c|c|c|c|c|c|c|c|c|c|c|c|}
\hline \multirow{2}{*}{$\begin{array}{l}\text { Carbon } \\
\text { source }^{a}\end{array}$} & \multicolumn{6}{|c|}{ Final concentration $(\mathrm{g} / \mathrm{L})^{\mathrm{b}}$} & \multicolumn{3}{|c|}{ Productivity $(\mathrm{g} / \mathrm{L} / \mathrm{h})^{\mathrm{c}}$} & \multicolumn{3}{|c|}{$\begin{array}{l}\text { Yield/substrate } \\
\text { (C-mol/C-mol) }\end{array}$} & \multicolumn{3}{|c|}{ Yield/final DCW (g/g) } \\
\hline & $\mathrm{B}^{\mathrm{d}}$ & $\mathrm{A}^{\mathrm{e}}$ & $E^{f}$ & $\mathrm{ABEg}$ & $\mathrm{AA}^{\mathrm{h}}$ & $\mathrm{BA}^{\mathrm{i}}$ & $\mathrm{B}^{\mathrm{d}}$ & $\mathrm{A}^{\mathrm{e}}$ & $E^{f}$ & $\mathrm{~B}^{\mathrm{d}}$ & $\mathrm{A}^{\mathrm{e}}$ & $E^{f}$ & $\mathrm{~B}^{\mathrm{d}}$ & $\mathrm{A}^{\mathrm{e}}$ & $E^{f}$ \\
\hline PG & 7.882 & 3.941 & 1.314 & 13.14 & 0.430 & 0.430 & 0.164 & 0.082 & 0.027 & 0.433 & 0.207 & 0.058 & 10.20 & 5.100 & 1.700 \\
\hline PS & 8.144 & 3.700 & 1.505 & 13.35 & 0.603 & 0.531 & 0.170 & 0.077 & 0.031 & 0.448 & 0.195 & 0.067 & 13.04 & 5.925 & 2.410 \\
\hline PT & 8.166 & 3.800 & 1.295 & 13.26 & 0.438 & 0.368 & 0.170 & 0.079 & 0.027 & 0.449 & 0.200 & 0.057 & 11.44 & 5.325 & 1.815 \\
\hline $\mathrm{R}$ & 7.575 & 3.621 & 1.298 & 12.49 & 0.579 & 0.344 & 0.158 & 0.075 & 0.027 & 0.436 & 0.199 & 0.060 & 12.31 & 5.884 & 2.110 \\
\hline $\mathrm{SC}$ & 8.759 & 4.592 & 1.289 & 14.64 & 0.469 & 0.336 & 0.182 & 0.096 & 0.027 & 0.481 & 0.241 & 0.057 & 11.57 & 6.066 & 1.703 \\
\hline SPC & 8.161 & 3.635 & 1.213 & 13.01 & 0.413 & 0.449 & 0.170 & 0.076 & 0.025 & 0.448 & 0.191 & 0.054 & 11.19 & 4.983 & 1.663 \\
\hline SPP & 7.819 & 5.140 & 0.992 & 13.95 & 0.327 & 0.225 & 0.163 & 0.107 & 0.021 & 0.429 & 0.270 & 0.044 & 8.935 & 5.874 & 1.134 \\
\hline
\end{tabular}

a Used in refresh media $15 \% \mathrm{w} / \mathrm{v} ; P G$ indicates potato (granola); $P S$ indicates potato (small); $P T$ indicates potato (Tess); $R$ indicates rice; $S C$ indicates sweet corn; SPC indicates sweet potato (Cilembu); SPP indicates sweet potato (purple)

b Measured at 48 hours of fermentation

Calculated as the average rate during 48 hours of fermentation

d Butanol, e acetone, ${ }^{\mathrm{f}}$ ethanol, $\mathrm{g}$ total solvents produced, $\mathrm{h}$ acetic acid, ${ }^{\mathrm{i}}$ butyric acid

Table 4 ABE fermentation using several carbon sources in refreshment and fermentation via C. saccharoperbutylacetonicum N1-4 ATCC (13564)

\begin{tabular}{|c|c|c|c|c|c|c|c|c|}
\hline \multirow{2}{*}{$\begin{array}{l}\text { Carbon source in } \\
\text { refreshment }\end{array}$} & \multirow{2}{*}{$\begin{array}{l}\text { Carbon source } \\
\text { in fermentation }\end{array}$} & \multicolumn{2}{|c|}{$\begin{array}{l}\text { Final concentration } \\
\qquad(\mathrm{g} / \mathrm{L})\end{array}$} & \multicolumn{2}{|c|}{$\begin{array}{c}\text { Yield per } \\
\text { substrate (\%) }\end{array}$} & \multicolumn{2}{|c|}{$\begin{array}{l}\text { Productivity } \\
\text { (g/L/h) }\end{array}$} & \multirow[t]{2}{*}{ Reference } \\
\hline & & $\mathrm{B}^{\mathrm{a}}$ & $\mathrm{ABE}^{\mathrm{b}}$ & $\mathrm{B}^{\mathrm{a}}$ & $\mathrm{ABE}^{\mathrm{b}}$ & $\mathrm{B}^{\mathrm{a}}$ & $\mathrm{ABE}^{\mathrm{b}}$ & \\
\hline Potato glucose & Glucose & 9.00 & 12.0 & 29.0 & 40.0 & 0.188 & 0.520 & (Ambarsari and Sonomoto, 2015) \\
\hline Potato glucose & Tapioca & 5.03 & 6.29 & 29.3 & 358 & 0.205 & 0.526 & (Ambarsari and Sonomoto, 2012) \\
\hline Sweet corn glucose & TYA-glucose & 8.76 & 14.6 & 29.7 & 0.496 & 0.182 & 0.305 & The current study \\
\hline Potato (Tess) glucose & TYA-glucose & 8.17 & 13.3 & 27.7 & 0.449 & 0.170 & 0.276 & The current study \\
\hline
\end{tabular}

a Butanol, b acetone, butanol, and ethanol (total solvents) produced 
refreshment media resulted in the lowest $\mathrm{pH}$ of the fermentation media (Table 1), and it grew the highest cell density, consuming higher substrates of both sugar (Table 2) and, consequently, acid. The sweet corn refreshment media, which produced the highest concentration of butanol, achieved the second-lowest residual butyric acid concentration, at $0.336 \mathrm{~g} / \mathrm{L}$. Its slightly lower dry cell weight of $0.7570 \mathrm{~g} / \mathrm{L}$, versus the purple sweet potato refreshment media's $0.8751 \mathrm{~g} / \mathrm{L}$, reduced its sugar consumption for cell growth, resulting in a greater energy supply to convert butyric acid into butanol (Li et al., 2020).

The solvents' average productivity was calculated as average values during 48 hours of fermentation (Table 3). The highest productivities of butanol and solvents were achieved using the sweet corn refreshment media, at 0.182 and $0.305 \mathrm{~g} / \mathrm{L} / \mathrm{h}$, respectively. The rice refreshment media achieved the lowest-productivity fermentation, at $0.158 \mathrm{~g} / \mathrm{L} / \mathrm{h}$ of butanol. This result was similar to previous studies' findings from batch fermentation using potato refreshment media with glucose as a substrate in the main fermentation of 0.188 $\mathrm{g} / \mathrm{L} / \mathrm{h}$ butanol (Ambarsari and Sonomoto, 2012).

In the current study, a high yield of butanol over $0.4 \mathrm{C}$-mol/C-mol was obtained during fermentation using all refresh media (Table 3). The highest yield resulted from the sweet corn refreshment media, at $0.481 \mathrm{C}-\mathrm{mol} / \mathrm{C}-\mathrm{mol}$, equal to $0.297 \mathrm{~g} / \mathrm{g}$ of glucose. This result was similar to a previous study using a similar formulation of refreshment media with potato, which achieved a yield of $0.293 \mathrm{~g} / \mathrm{g}$ (Ambarsari and Sonomoto, 2012). Surprisingly, the sweet corn refreshment media provided the highest yields compared to previous studies (Table 4), at $0.297 \mathrm{~g}$ of butanol/g glucose and $0.496 \mathrm{~g}$ solvents/g glucose.

The refreshment media contained glucose, ammonium sulfate, calcium carbonate, and $15 \%$ starchy vegetables. Glucose was used as the primary carbon source, which is necessary to grow the first simple sugar needed for strain energy (Al-Shorgani et al., 2018). Ammonium sulfate was the nitrogen source for cell development (Ferchichi et al., 2005), and calcium carbonate was the buffering agent for the media and also stimulated enzyme activity for starch consumption (Li et al., 2015). Starchy vegetables were added as the source of natural sugars and starch. The addition of this material successfully activated the strain's enzyme to digest a wider variety of simple and complex sugars, such as xylose, arabinose, cellobiose, and starch than other strain without starchy vegetables in refreshment process (Li et al., 2015; Thang et al., 2010). Sweet corn comprises 8-16\% sugars on a dry basis, while the remainder principally comprises starch at up to 45\% (Surtinah, 2008). Trace elementssuch as nitrogen, phosphor, potassium, magnesium, and sulfur-are fermentationsupporting components in sweet corn. All the starchy materials studied in the current paper's experiment resulted in a remarkable performance, with sweet corn producing the highest final butanol concentration, productivity, and yield.

\section{Conclusions}

We studied starchy materials' potency for the refreshment process of $C$. saccharoperbutylacetonicum N1-4 fermentation, using materials that were extensively produced around the world. Potato, rice, sweetcorn, and sweet potato resulted in remarkable butanol concentrations, ranging from 7.58 to $8.76 \mathrm{~g} / \mathrm{L}$. Compared with the previous literature, our study's fermentation using sweet corn as a refreshment media yielded total solvents of $0.496 \mathrm{~g} / \mathrm{g}$. Our use of sweet corn as a refreshment substrate resulted in our study's highest butanol concentration, productivity, and yield because of the supporting minerals present in sweet corn. A further study is required to apply this study's method to larger-scale fermentation in order to understand sweet corn's application as a refreshment substrate in larger-capacity and longer operations. 


\section{Acknowledgements}

The authors acknowledge the Ministry of Education and Culture, Indonesia. This work was supported by the Islamic Development Bank Supporting Program, University of Jember, Indonesia. We have no conflicts of interest to declare.

\section{References}

Al-Shorgani, N.K.N., Kalil, M.S., Yusoff, W.M.W., Hamid, A.A., 2018. Impact of pH and Butyric Acid on Butanol Production during Batch Fermentation using a New Local Isolate of Clostridium Acetobutylicum YM1. Saudi Journal of Biological Sciences, Volume 25(2), pp. 339-348

Ambarsari, H., Sonomoto, K., 2012. Enhanced Acetone, Butanol, and Ethanol Fermentation by Clostridium Accharoperbutylacetonicum N1-4 (ATCC 13564) in a Chemically Defined Medium: Effect of Iron and Initial pH on ABE Ratio. Microbiology Indonesia, Volume 6(4), pp. 139-147

Ambarsari, H., Sonomoto, K., 2015. Acetone-Butanol-Ethanol Fermentation for Bioenergy using Various Substrates in Defined TYA Media. Jurnal Energi Dan Lingkungan (Enerlink), Volume 11(1), pp. 49-60

Darmayanti, R.F., Amini, H.W., Rizkiana, M.F., Setiawan, F.A., Palupi, B., Rahmawati, I., Susanti, A., Fachri, B.A., 2019. Lignocellulosic Material from Main Indonesian Plantation Commodity as the Feedstock for Fermentable Sugar in Biofuel Production. ARPN Journal of Engineering and Applied Sciences, Volume 14(20), pp. 3524-3534

Darmayanti, R.F., Tashiro, Y., Noguchi, T., Gao, M., Sakai, K., Sonomoto, K., 2018. Novel Biobutanol Fermentation at a Large Extractant Volume Ratio using Immobilized Clostridium Saccharoperbutylacetonicum N1-4. Journal of Bioscience and Bioengineering, Volume 126(6), pp. 750-757

Devaux, A., Kromann, P., Ortiz, O., 2014. Potatoes for Sustainable Global Food Security. Potato Research, Volume 57(3), pp. 185-199

Febrianti, F., Syamsu, K., Rahayuningsih, M., 2017. Bioethanol Production from Tofu Waste by Simultaneous Saccharification and Fermentation (SSF) using Microbial Consortium. International Journal of Technology, Volume 8(5), pp. 898-908

Ferchichi, M., Crabbe, E., Hintz, W., Gil, G.-H., Almadidy, A., 2005. Influence of Culture Parameters on Biological Hydrogen Production by Clostridium saccharoperbutylacetonicum ATCC 27021. World Journal of Microbiology and Biotechnology, Volume 21(6), p. 855-862

Firgianti, G., Sunyoto, M., 2018. Karakterisasi Fisik dan Kimia Ubi Jalar Ungu (Ipomoea Batatas L ) Varietas Biang untuk Mendukung Penyediaan Bahan Baku Tepung Ubi Jalar Ungu (Physical and Chemical Characterization of Purple Sweet Potato (Ipomoea batatas) Biang Variety to Support the Feedstock Supply for Purple Sweet Potato Flour). In: Seminar Nasional Dies Natalis UNS Ke-42 (National Seminar of 42nd UNS Anniversary), Volume 2(1), pp. 104-110

Gao, M., Tashiro, Y., Wang, Q., Sakai, K., Sonomoto, K., 2016. High Acetone-Butanol-Ethanol Production in pH-Stat Co-Feeding of Acetate and Glucose. Journal of Bioscience and Bioengineering, Volume 122(2), pp. 176-182

Hastuti, N., Darmayanti, R.F., Hardiningtyas, S.D., Kanomata, K., Sonomoto, K., Goto, M., Kitaoka, T., 2019. Nanocellulose from Oil Palm Biomass to Enhance Microbial Fermentation of Butanol for Bioenergy Applications. BioResources, Volume 14(3), pp. 6936-6957

Jusuf, M., Ginting, E., 2014. The Prospects and Challenges of Sweet Potato as Bio-Ethanol 
Source in Indonesia. Energy Procedia, Volume 47, pp. 173-179

Kim, S.Y., Ryu, C.H., 1995. Studies on the Nutritional Components of Purple Sweet Potato(Ipomoea Batatas). Korean Journal of Food Science and Technology, Volume 27(5), pp. 819-825

Lapuerta, M., Ballesteros, R., Barba, J., 2017. Strategies to Introduce n-Butanol in Gasoline Blends. Sustainability (Switzerland), Volume 9(4), pp. 589-598

Li, H-g., Luo, W., Wang, Q., Yu, X-b., 2014. Direct Fermentation of Gelatinized Cassava Starch to Acetone, Butanol , and Ethanol using Clostridium Acetobutylicum Mutant Obtained by Atmospheric and Room Temperature Plasma. Applied Biochemistry and Biotechnology, Volume 172(7), pp. 3330-3341

Li, S.-Y., Srivastava, R., Suib, S.L., Li, Y., Parnas, R.S., 2011. Performance of Batch, Fed-Batch, and Continuous A-B-E Fermentation with pH-Control. Bioresource Technology, Volume 102(5), pp. 4241-4250

Li, S., Huang, L., Ke, C., Pang, Z., Liu, L., 2020. Pathway Dissection, Regulation, Engineering and Application: Lessons Learned from Biobutanol Production by Solventogenic Clostridia. Biotechnology for Biofuels, Volume 13(39), pp. 1-25

Li, T., Yan, Y., He, J., 2015. Enhanced Direct Fermentation of Cassava to Butanol by Clostridium Species Strain BOH3 in Cofactor-Mediated Medium. Biotechnology for Biofuels, Volume 8(166), pp. 1-12

Liu, K., Zheng, J., Wang, X., Chen, F., 2019. Effects of Household Cooking Processes on Mineral, Vitamin B, and Phytic Acid Contents and Mineral Bioaccessibility in Rice. Food Chemistry, Volume 280, pp. 59-64

McGill, C.R., Kurilich, A.C., Davignon, J., 2013. The Role of Potatoes and Potato Components in Cardiometabolic Health: A Review. Annals of Medicine, Volume 45(7), pp. 467-473

Merola, S.S., Tornatore, C., Marchitto, L., Valentino, G., Corcione, F.E., 2012. Experimental Investigations of Butanol-Gasoline Blends Effects on the Combustion Process in a SI Engine. International Journal of Energy and Environmental Engineering, Volume 3(6), pp. $1-14$

Mukherjee, M., Sarkar, P., Goswami, G., Das, D., 2019. Regulation of Butanol Biosynthesis in Clostridium Acetobutylicum ATCC 824 under the Influence of Zinc Supplementation and Magnesium Starvation. Enzyme and Microbial Technology, Volume 129, 109352. https://doi.org/10.1016/j.enzmictec.2019.05.009

Muthayya, S., Sugimoto, J.D., Montgomery, S., Maberly, G.F., 2014. An Overview of Global Rice Production, Supply, Trade, and Consumption. Annals of the New York Academy of Sciences, Volume 1324(1), pp. 7-14

Oshiro, M., Hanada, K., Tashiro, Y., Sonomoto, K., 2010. Efficient Conversion of Lactic Acid to Butanol with pH-Stat Continuous Lactic Acid and Glucose Feeding Method by Clostridium Saccharoperbutylacetonicum. Applied Microbiology and Biotechnology, Volume 87(3), pp. 1177-1185

Qureshi, N., Singh, V., Liu, S., Ezeji, T.C., Saha, B.C., Cotta, M.A. 2014. Process Integration for Simultaneous Saccharification, Fermentation, and Recovery (SSFR): Production of Butanol from Corn Stover using Clostridium Beijerinckii P260. Bioresource Technology, Volume 154, pp. 222-228

Sari, F.K., Nurhayati., Djumarti., 2013. The Extraction of Starch Resistant from Three Local Varieties Potatoes as Prebiotic Candidates. Berkala Ilmiah Pertanian, Volume 1, pp. 3842

Supramono, D., Jonathan., Haqqyana., Setiadi., Nasikin, M., 2016. Improving Bio-oil Quality Through Co-pyrolysis of Corn Cobs and Polypropylene in a Stirred Tank Reactor, International Journal of Technology, Volume 7(8), pp. 1382-1392 
Surtinah., 2008. Waktu Panen yang Tepat Menentukan Kandungan Gula Biji Jagung Manis (Zea Mays Saccharata) (The Precise Harvesting Time to Determine Sugar Content of Sweet Corn Kernel (Zea mays saccharata)). Jurnal Ilmiah Pertanian, Volume 4(2), pp. 56

Szulczyk, K.R., 2010. Which Is a Better Transportation Fuel-Butanol or Ethanol?. International Journal of Energy and Environment, Volume 1(3), pp. 501-512

Tashiro, Y., Takeda, K., Kobayashi, G., Sonomoto, K., Ishizaki, A., Yoshino, S., 2004. High Butanol Production by Clostridium Saccharoperbutylacetonicum N1-4 in Fed-Batch Culture with pH-Stat Continuous Butyric Acid and Glucose Feeding Method. Journal of Bioscience and Bioengineering, Volume 98(4), 263-268

Tashiro, Y., Yoshida, T., Noguchi, T., Sonomoto, K., 2013. Recent Advances and Future Prospects for Increased Butanol Production by Acetone-Butanol-Ethanol Fermentation. Engineering in Life Sciences, Volume 13(5), pp. 432-445

Thang, V.H., Kanda, K., Kobayashi, G., 2010. Production of Acetone-Butanol-Ethanol (ABE) in Direct Fermentation of Cassava by Clostridium Saccharoperbutylacetonicum N1-4. Applied Biochemistry and Biotechnology, Volume 161(1), pp. 157-170

Xue, C., Zhao, J., Lu, C., Yang, S.T., Bai, F., Tang, I.C., 2012. High-Titer n-Butanol Production by Clostridium Acetobutylicum JB200 in Fed-Batch Fermentation with Intermittent Gas Stripping. Biotechnology and Bioengineering, Volume 109(11), pp. 2746-2756

Yuliansyah, A.T., Putri, C.O., Clarasinta, B.D., Nonaka, M., 2019. TGA Investigation of $\mathrm{CO}_{2}$ Gasification of Hydrothermally Treated Biomass (Corn Cob - Coconut Shell Mixture). International Journal of Technology, Volume 10(6), pp. 1166-1173

Zhao, T., Tashiro, Y., Zheng, J., Sakai, K., Sonomoto, K., 2018. Semi-Hydrolysis with Low Enzyme Loading Leads to Highly Effective Butanol Fermentation. Bioresource Technology, Volume 264, pp. 335-342

Zhao, T., Yasuda, K., Tashiro, Y., Darmayanti, R.F., Sakai, K., Sonomoto, K., 2019. SemiHydrolysate of Paper Pulp without Pretreatment Enables a Consolidated Fermentation System with in Situ Product Recovery for the Production of Butanol. Bioresource Technology, Volume 278, pp. 57-65 